\title{
Vievätkö hyvät käytännöt opetuksessa hyvään oppimiseen?
}

\author{
JORMAKAJAVA \& JUHANI ANTTILA
}

50-vuotiaan Oulun yliopiston juhlavuoden tilaisuuksiin liittyy toukokuussa OpinTori 2008 -tapahtuma. Sen tavoitteena on levittää opetuksen, ohjauksen ja opiskelun hyviä käytäntöjä sekä lisätä opetuksen arvostusta ja edistää opettajien mahdollisuutta meritoitua opetuksen kehittämistyössä.

Hyvästä oppimisesta ei ole mainintaa, vaikkakin se luonnollisesti on hyvän opetuksen tarkoituksena. Kuitenkin haasteena on Ivan Illichin (1970) esille tuoma deschooling, jonka mukaan

"Kouluissa oppilaat ehdollistetaan sotkemaan keskenään opetus ja oppiminen, edistyminen ja tutkinnot. He menettävät kyvyn sanoa jotain uutta ja omaa. Mitä enemmän opettajia, sitä enemmän oppimattomuutta! Sama toistuu muilla yhteiskuntasektoreilla.”

Olemme läheltä seuranneet yliopistojen koulutusta useampia vuosikymmeniä. Jos on ollut vastuussa alimpien vuosikurssien opetuksesta, sitä ei ole arvostettu silloin, kun yliopiston laitoksen koko opetusprosessi tuottaa hyviä tuloksia. Kun koulutusjakson lopussa on hämminkiä, silloin helposti etsitään syytä ketjun alusta. Nyt elämme aikoja, jolloin alkuopetukseen on alettu kiinnittää korostetusti huomiota, jotta saataisiin parhaat voimat osallistumaan siihen.

Kokemuksemme liittyy myös yliopiston tietojenkäsittelyopin opintojen puoliväliin ja loppuosaan. Jos opettaja pystyy ketjuttamaan sanomansa useammalle kurssille ja pitemmälle ajanjaksolle, niin sen vaikuttavuus on syvällisempi. Esimerkiksi työharjoittelun ja laajojen projektitöiden jaksoissa korostuu opittujen teoreettisten asioiden vieminen käytännön ongelmien ratkaisuiksi. Samalla syntyy usein myös keskinäinen luottamus, joka voi jatkua Pro gradu -tutkielmaan ja työelämään saakka. Toiminnassa onnistuttiin, kun opettajalla oli vain yksi ryhmä vastuullaan. Sen rinnalla oli toinen alemmalla vuosikurssilla oleva ryhmä. Ei puhuttu tutoroinnista, mutta oppilaat valmistuivat reilussa neljässä vuodessa.

Kun puhutaan parhaista käytännöistä opetuksen yhteydessä, se valpastuttaa opettajat. Eikö tavoitteena voisi olla linkki suoraan moderniin yhteiskuntaan? Historia voitaisiin jättää niille, jotka sitä opettavat. Parhaatkin käytännöt liittyvät siihen, mitä on sattunut ja miten vastaaviin tilanteisiin reagoidaan tulevaisuudessa. Näinkö pitäisi olla?

Työelämän eri aloilla tapahtuu voimakas muutosprosessi. Esimerkiksi tietotekniikan ammatit olivat vielä selkeitä 80-luvun alussa. Silloin puhuttiin reikäkorttilävistäjistä, ohjelmoijista, operaattoreista, suunnittelijoista ja tutkijoista. Ennen tietotekniikan työtehtäviin tultiin monesti työpaikkakoulutuksen kautta, hyvin usein ilman ammatillista tutkintoa. Myös ne opiskelijat, joilla oli jo opintojensa aikana valmiudet ja osaamista alan työtehtäviin, vietiin oppilaitoksista usein jo kesken opintojen. Nyt vanhat toimenkuvat ovat muuttuneet. Kaikilta tietotekniikan ammattilaisilta vaaditaan laajaa alan osaamista, niin yksityiskohtien kuin mutkikkaiden kokonaisuuksienkin ymmärtämistä. Tämäkään ei enää riitä, vaan tarvitaan myös henkilöitä, jotka ovat perehtyneet jollekin erityisosaamista vaativalle alueelle syvällisesti, esimerkiksi tietoturvallisuuteen.

Viiden vuoden yliopisto-opintojen aikana tilanne työelämässä muuttuu jopa radikaalisti. Osa vanhoista asioista muuttuu itsestäänselvyyksiksi ja ne voisi jättää pois opetusohjelmasta. Tiedon puoliintumisaika lyhenee. Samalla tulee esille jatkuvasti uusia asioita, joita samanaikaisesti on esillä paljon eri asiayhteyksissä. Tarvitaan sekä yleistietämystä asioista että kontekstuaalista tietoa niin tapauskohtaista tietoa kuin tilannekohtaista fokusoitua tietoa. Samalla tulee jatkuvasti uusia vaatimuksia. Myös tietotekniikan osalta tulee teollisuudesta vihjeitä opetettavista kursseista. Kuitenkaan yliopistokoulutus ei saa johtaa yksittäisten tuotemerkkien ja erillisten työkalujen opettamiseen, vaan siihen, miten toimitaan tilanteessa, 


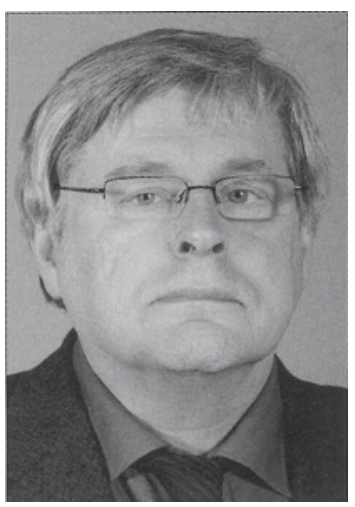

Jorma Kajava

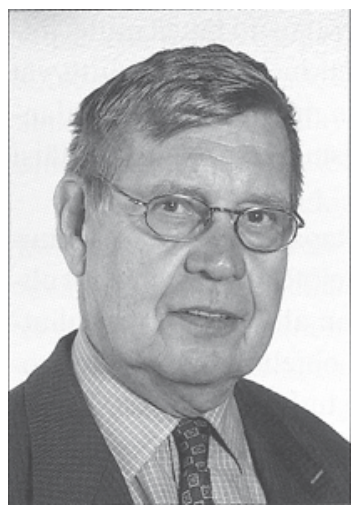

Juhani Anttila johon ei ole valmista malliratkaisua olemassa. Koulutuksen on myös sisältönsä puitteissa elettävä muun yhteiskunnan tahdissa, proaktiivisesti.

Jos suunnittelija nojaa työssään vanhaan, tilannetta voidaan verrata niin sanottujen kypsyysmallien (Capability Maturity Model Integration CMMI -mallien) käyttämiseen (Software Engineering Institute 2007). Käytännössä tämä voi tarkoittaa sitä, että vaaditaan pysymään paikallaan, pitäytymään vanhassa. Kun tietoturvallisuuden hallinnassa puhutaan ISO IEC 27000 standardeista (ISO 2005), tarkoitetaan pitäytymistä olemassa olevissa käytännöissä, koska standardi perustuu best practices -kontrolleihin. Kuitenkin, moderni menestyminen ei onnistu vanhoilla malleilla, sen pitäisi perustua exellence -malleihin, joilla tähdätään oppimiseen ja ylivertaisuuteen.

\section{Proaktiivisuus ja win/win}

Parhaat käytännöt ovat herättäneet positiivisia mielikuvia opetuksen ydinasioista. Ne ovat kuitenkin nyt saaneet uuden tulkinnan, past practices. Ei riitä opetuksessa, että pelkästään pyrittäisiin elvyttämään vanhoja käytäntöjä, vaan niiden lisäksi on ymmärrettävä uudet tarpeet ja niiden vaikutus koulutukseen. Koulutuksesta vastuussa olevien on nähtävä tämän päivän tarpeiden lisäksi huomisen tarpeet.

Proaktiivisuus tarkoittaa sitä, että on varauduttava tilanteisiin, jotka ovat täysin uusia ja ennalta arvaamattomia. Hyviksi koetuista käytännöistäkin pitäisi oppia edelleen. No, kuinka sitten? Kuinka voidaan opettaa ja valmentaa oppilaita sellaiseen, mikä vasta on tulossa - ensi viikolla tai viiden vuoden kuluttua?
Best practices -käytännöistä pitäisi päästä eteenpäin, niihin liittyvän explisiittisen tiedon lisäksi pitäisi pystyä porautumaan siihen, kuka tietää ja kenellä on tietoa ja kokemuksia niiden hyödyntämisestä. Best practices -käytännöistä opitaan edelleen niiden hyödyntämisen kautta.

Opetuksen rakenteet esitetään koulutusohjelmien muodossa. Rakenne on stabiili, se kestää vuosikausia. Yliopistojen "tuotteista", valmiista maistereista ja heidän osaamisestaan, on keskusteltu. Jos lopputuotteella tarkoitetaan maisteria tutkintotodistus kourassaan, niin siihen pitäisi ehdottomasti sisältyä tutkinnon lupaamaa osaamista ja valmiutta. Miksi koulutusjärjestelmä ei tuota valmiita tuotteita yhteiskunnan ja teollisuuden tarpeisiin?

Tulosvastuu ja tuotteiden lukumäärä vaikuttaa oleellisesti oppilaitoksen rahoitukseen jo nyt ja lähitulevaisuudessa. Kun pyritään maksimoimaan rahavirtoja, niin tuotteiden laatu yleensä kärsii. Vain harvoin proaktiiviset seikat sopivat tähän massatuotantoon, jota vielä niin sanottu Bolognan prosessi pyrkii jähmettämään muuttamattomuudellaan.

Kun ikäluokat pienevät, myös opetuksessa olisi nähtävä uudet mahdollisuudet. Oppilaiden määrä yhtä opettajaa kohti voi laskea. Mutta mitä tämä oikein tarkoittaa? Paraneeko tilanne? Huononeeko tilanne? Tässä tarvitaan ryhdistäytymistä, on päästävä parempaan oppimiseen

Työharjoittelulla olisi mahdollista kuroa teorian ja käytännön välistä kuilua. Kuitenkaan suomenkieli ei kuvaa asian koko laajuutta, jota ilmaistaan sanonnalla Progressive Sandwich Training (Kajava \& Varonen 1998, 2000 a \& b). Kunkin kokeneen opettajan olisi mahdollista rakentaa omaa tutkimuskentäänsä sivuavia projekteja, joissa toimittaisiin aluksi laboratorio-olosuhteissa, mutta myöhemmin mukaan tulisi myös käytännön sovelluksia yrityksissä tai muissa organisaatioissa (Kajava \& Varonen 2001, 2002). Projekteissa työskennellessään oppilaat näkisivät, mitkä valinnaiset opinnot ovat työn kannalta tärkeitä, ja suorittaisivat ne. Oikeasti oppiminen tapahtuu juuri verkostoissa informaalisti ("epämuodollisesti") (Siemens 2006, Anttila \& al 2007). Tietotekniikan villeinä vuosina parhaat opiskelijat vietiin kesken opintojaan työelämään. Yliopistoilla ja oppilaitoksilla voi nyt säilyä täysi ote toimintaan. Yhdessä toimien yliopisto ja teollisuus - mahdollistuu, että samalla myös yliopisto oppii (win/win -toiminta). 


\section{Life long learning}

Kun jotakin ehdottaa, niin helposti saa palautetta: Voisitko näyttää asian käytännössä? Kun toimii taiten, asian on voinut testata todellisessa ympäristössä. Asiat ovat abstrakteja, niitä ei ole helppo mitata. Ennen mittaamista on selvitettävä, mikä ilmiö on asian ytimenä. Eikö se ole juuri oppimisen ja tietyn osaamisvalmiuden saavuttaminen? Opettajana voi tyytyä mittaamaan, kuinka hyvin oppilaat ovat työllistyneet teollisuuden ja elinkeinoelämän tärkeissä asiantuntijatehtävissä.

Opettajalta vaaditaan riskinottokykyä. Riittääkö hänen osaamisensa työskentelyyn osaavien ja innovatiivisten nuorten parissa? Kun tarkastellaan oppimistilanteessa opettajaa ja opiskelijoita, niin kuka tekee työn? Oppilaat tekevät oppimistyön, opettajan on osattava astua sivuun oikealla hetkellä ja toimia valmentajana. Tärkeää on ymmärtää, että juuri opiskelijathan "virittävät” opettajankin uudelle tasolle.

Parhaita käytäntöjä tarvitaan opetuksessa jatkossakin. Tienviittana uuteen ajatteluun voi olla Jay Crossin Informal Learning, the other 80\% (Cross, J. 2003, Anttila 2007). Oppiminen on modernissa yhteiskunnassa keskeinen elementti, sen merkitys jatkuu koko ihmisen elämän kaaren. Yliopistoissa ja oppilaitoksissa opiskellaan vain lyhyen ajanjakson ajan, sen sijaan oppiminen jatkuu monine jaksoineen life long - long life, live learning.

\section{Lähteet}

Anttila, J., Savola, R., Kajava, J., Lindfors, J., Röning, J. (2007). Fulfilling the needs for information security awareness and learning in information society. In G. Dhillon (ed.): 6th Annual Security Conference - Assuring Business Processes. Las Vegas, VD, USA. http:// www.security-conference.org/

Anttila, J. (2008): Advanced Web 2.0 based interactive technology to support informal learning for enhancing quality of business management. ICELW 2008. New York. USA.

Cross, J. (2003): Informal Learning, the other 80\%. Internet Time Group. Berkeley, California. http://internettime.com/Learning/ The\%20Other\%2080\%25.htm

Illich., I. (1970). Deschooling society. Center for Intercultural Documentation (CIDOC). Cuernavaca, Mexico. Verkkoon toimittanut Paul
Knatz http://reactor-core.org/deschooling.html ISO (2005). ISO/IEC 27002 (17799) - Information technology - Security techniques - Code of practice for information security management. Geneve. Schwitzerland.

Kajava, J., Varonen, R. (1998): Progressive sandwich training - A gateway between industry and IT education at universities. In N. J. Buch \&al (eds.): Information systems research in collaboration with industry. IRIS 21. Aalborg, Denmark.

Kajava, J., Varonen, R. (2000a): The professional growth of ICT experts through progressive sandwich training. In J. Tarhio, S. Fincher \& D. Joyce (eds.): 5th Annual SIGSE/SIGCUE Conference on Innovation and Technology in Computer Science Education (ITiCSE 2000). ACM Press. New York, USA. http:// www.cs.helsinki.fi/events/iticse/poster/ index.html\#abs30

Kajava, J., Varonen, R. (2000b): Progressive Sandwich Training in the Professional Growth of ICT Experts. In Eveline Riedling and Gordon Davies (eds.): ED-ICT 2000. Information and Communication Technologies for Education. OCG and ACM SIGCSE. books@ocg. at BAND 146. Vienna, Austria.

Kajava, J., Varonen, R. (2001): In search of balance between studies and work - Informatics seek to combine practice and theory into knowledge. In Bjørnestad, S. \& al (eds.): Knowledge Systems. IRIS 24 . Bergen, Norway.

Kajava, J., Varonen, R. (2002): Balancing Studies and Work - Practice and Theory in Information Processing Education. Online Journal TELMAE, Vol. TET 01. Prague, Czech Republic.

Siemens, G. (2006): Knowing knowledge. Complexive Inc. Manitoba, Canada. http://knowing knowledge.com

Software Engineering Institute (2007): Capability Maturity Model Integration, CMMI for Acquisition, Version 1.2 CMMI. Product team improving processes for acquiring better products and services. TECHNICAL REPORT CMU/SEI-2007-TR-017. Carnegie Mellon University. Carnegie Mellon. USA. http://www.sei. cmu.edu/pub/documents/07.reports/07tr017.pdf 